\title{
Expression of Selected microRNAs in Migraine: A New Class of Possible Biomarkers of Disease?
}

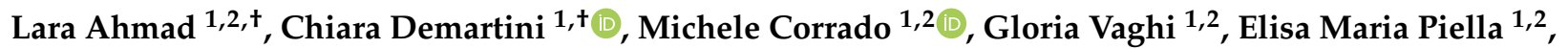 \\ Marta Allena ${ }^{1}$, Anna Maria Zanaboni ${ }^{1,2}$, Rosaria Greco ${ }^{1}$, Cristina Tassorelli ${ }^{1,2}$ and Roberto De Icco 1,2,*(D)
}

1 Headache Science \& Neurorehabilitation Center, IRCCS Mondino Foundation, 27100 Pavia, Italy; lara.ahmad01@universitadipavia.it (L.A.); chiara.demartini@mondino.it (C.D.); michele.corrado01@universitadipavia.it (M.C.); gloria.vaghi@gmail.com (G.V.); elisamaria.piella01@universitadipavia.it (E.M.P.); marta.allena@mondino.it (M.A.); annamaria.zanaboni@mondino.it (A.M.Z.); rosaria.greco@mondino.it (R.G.); cristina.tassorelli@mondino.it (C.T.)

2 Department of Brain and Behavioral Sciences, University of Pavia, 27100 Pavia, Italy

* Correspondence: roberto.deicco@mondino.it; Tel.: +39-0382-380387

+ These authors contributed equally.

Citation: Ahmad, L.; Demartini, C.; Corrado, M.; Vaghi, G.; Piella, E.M.; Allena, M.; Zanaboni, A.M.; Greco, R.; Tassorelli, C.; De Icco, R. Expression of Selected microRNAs in Migraine: A New Class of Possible Biomarkers of Disease? Processes 2021, 9, 2199. https://doi.org/10.3390/pr9122199

Academic Editor: Hsiuying Wang

Received: 18 October 2021

Accepted: 3 December 2021

Published: 6 December 2021

Publisher's Note: MDPI stays neutral with regard to jurisdictional claims in published maps and institutional affiliations.

Copyright: (C) 2021 by the authors. Licensee MDPI, Basel, Switzerland. This article is an open access article distributed under the terms and conditions of the Creative Commons Attribution (CC BY) license (https:/ / creativecommons.org/licenses/by/ $4.0 /)$.

\begin{abstract}
Preliminary but convergent findings suggest a role for microRNAs (miRNAs) in the generation and maintenance of chronic pain and migraine. Initial observations showed that serum levels of miR-382-5p and miR-34a-5p expression were increased in serum during the migraine attack, with miR-382-5p increasing in the interictal phase as well. By contrast, miR-30a-5p levels were lower in migraine patients compared to healthy controls. Of note, antimigraine treatments proved to be capable of influencing the expression of these miRNAs. Altogether, these observations suggest that miRNAs may represent migraine biomarkers, but several points are yet to be elucidated. A major concern is that these miRNAs are altered in a broad spectrum of painful and non-painful conditions, and thus it is not possible to consider them as truly "migraine-specific" biomarkers. We feel that these miRNAs may represent useful tools to uncover and define different phenotypes across the migraine spectrum with different treatment susceptibilities and clinical features, although further studies are needed to confirm our hypothesis. In this narrative review we provide an update and a critical analysis of available data on miRNAs and migraines in order to propose possible interpretations. Our main objective is to stimulate research in an area that holds promise when it comes to providing reliable biomarkers for theoretical and practical scientific advances.
\end{abstract}

Keywords: miRNA; biomarker; pain; headache; CGRP

\section{Introduction}

Migraine is a primary headache disorder defined by the recurrence of attacks of throbbing pain typically located on one side of the head, with medium-high intensity, worsening with routine physical activities. The attacks last from 4 to $72 \mathrm{~h}$. The pain is often accompanied by photo- and/or phonophobia and nausea and/or vomiting [1]. In around $30 \%$ of patients, a headache is preceded by visual, sensitive or aphasic symptoms, defining a subtype of the disease spectrum called "migraine with aura" [1].

According to the Global Burden of Disease Study 2019, migraine is the second most disabling disease in terms of years lived with disability [2]. In addition to the burden on personal life, migraine has a negative impact on multiple areas of the lives of those affected (school, social activities, work), resulting in a huge socio-economic impact on society [3,4].

Depending on the median frequency of headache, migraine is defined as episodic migraine (EM) for those who have less than 15 headache days per month, or chronic migraine $(\mathrm{CM})$ in those who have at least 15 headache days per month, 8 of which with migraine features, for at least three months [1]. Chronification of migraine is often associated with a progressive increase in the intake of acute medications, a condition known 
as Medication Overuse Headache (MOH) [1]. A prompt diagnosis of $\mathrm{MOH}$ is mandatory because a specific treatment, namely the withdrawal of acute medications, is generally recommended [5].

The diagnosis of migraine is clinical, based on an accurate history, neurological examination and the satisfaction of the precise criteria of the International Classification of Headaches Disorders (ICHD-3) [1]. The pathogenesis of migraine is multifactorial and involves multiple peripheral and central processes. A crucial role is played by the activation of the trigeminovascular system, while cortical spreading depression is considered the underlying mechanism of migraine aura [6].

So far, validated and reliable biomarkers of migraine are lacking, but the headache scientific community is intensely investigating the neurobiological signatures of migraine to develop biomarkers and druggable targets [7].

Pre-clinical and clinical studies have yielded an impressive list of potential neurophysiological, neuroimaging and biochemical biomarkers of migraine, which are summarized in Table 1. Several molecules proved relevant for the activation and the sensitization of the structures of the trigeminovascular system, including calcitonin gene-related peptide (CGRP), pituitary adenylate cyclase-activating polypeptide (PACAP), vasoactive intestinal peptide (VIP) and substance P [8]. Unfortunately, the clinical application of these biomarkers is limited by the lack of consistency across studies and, in some cases, by the lack of disease specificity.

Another class of molecules that has recently gained interest as putative biomarkers for migraine is represented by microRNAs (miRNAs), the short non-coding filaments of RNA (made of about 22 nucleotides) [9,10]. miRNAs regulate gene expression posttranscriptionally via, but not limited to, the interaction with the $3^{\prime}$ untranslated region of target mRNAs, promoting their degradation and translational repression [11].

miRNAs were first discovered in 1993 in Caenorhabditis elegans, and since then they have been found in all eukaryotic cells conserved across the species [12]. miRNAs could be considered epigenetic regulators of fundamental biological processes such as proliferation, differentiation, survival and apoptosis in many cell types [13], where they are moved among the subcellular compartments to regulate the translation and transcriptional rate [14].

Recent evidence analyses their hypothetical role as causative agents, biomarkers and therapeutic targets in a wide range of neoplastic, inflammatory, autoimmune and cardiovascular diseases $[15,16]$. For each disease, one or more specific miRNAs have been identified and suggested in relation to different aspects, namely pathophysiology, diagnosis, follow-up and treatment, thus confirming the huge potential role of miRNAs in this context. Moreover, the inhibition mechanisms of miRNAs are characterized by complex interactions between miRNAs and mRNAs. Indeed, one single miRNA can target multiple genes but at the same time, one gene can be targeted by multiple miRNAs [17].

The need for specific biomarkers for migraine is an outstanding issue. In this review, we will present an update and a critical analysis of available data on miRNAs and migraine. We will also summarize their role in other pain conditions to provide readers with a foundation for critically interpreting available evidence on miRNAs in migraine. We will focus specifically on miR-382-5p, miR-34a-5p and miR-30a, and we will discuss the pain-related mechanisms that may implicate them in migraine-related mechanisms. This overview will hopefully stimulate further research in an area that holds promise in the context of advancing the understanding and management of migraine. 


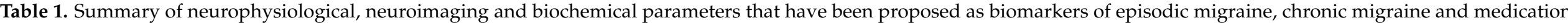
overuse headache.

\begin{tabular}{|c|c|c|c|c|c|c|}
\hline & \multicolumn{2}{|c|}{ Neurophysiology } & \multicolumn{2}{|l|}{ Neuroimaging } & \multicolumn{2}{|c|}{ Biochemistry } \\
\hline \multirow{3}{*}{ EM } & $\begin{array}{c}\downarrow \downarrow \downarrow \text { habituation of VEP } \\
\uparrow \uparrow \uparrow \text { IDAP between attacks }\end{array}$ & Ambrosini et al. (2017) [18] & $\begin{array}{l}\downarrow \downarrow \downarrow \text { volume of insula, frontal/prefrontal, temporal, } \\
\text { parietal, occipital cortices, anterior cingulate cortex, } \\
\text { basal ganglia and cerebellum }\end{array}$ & Ashina et al. (2021) [19] & $\begin{array}{l}\uparrow \uparrow \uparrow \text { levels of CGRP and } \\
\text { Substance } P \text { in the interictal phase }\end{array}$ & Fusayasu et al. (2007) [20] \\
\hline & $\begin{array}{l}\downarrow \downarrow \downarrow \text { habituation of the nBR in } \\
\text { the interictal phase }\end{array}$ & $\begin{array}{l}\text { Di Clemente et al. (2007) [21] } \\
\text { Perrotta et al. (2017) [22] }\end{array}$ & $\uparrow \uparrow \uparrow$ deep white matter hyperintensities in women & Palm-Meinders et al. (2012) [23] & $\begin{array}{l}\uparrow \uparrow \uparrow \text { VIP plasma level in the } \\
\text { interictal phase }\end{array}$ & $\begin{array}{l}\text { Cernuda-Morollon et al. (2015) } \\
\text { [24] }\end{array}$ \\
\hline & $\begin{array}{l}\downarrow \downarrow \downarrow \text { TST of the NWR after NTG } \\
\text { administration }\end{array}$ & De Icco et al. (2020) [25] & $\begin{array}{l}\uparrow \uparrow \uparrow \text { hypothalamus activity within the last } 24 \mathrm{~h} \\
\text { preceding the onset of migraine pain } \\
\uparrow \uparrow \uparrow \text { functional coupling between hypothalamus and } \\
\text { the spinal trigeminal nucleus }\end{array}$ & Schulte et al. (2016) [26] & $\begin{array}{l}\downarrow \downarrow \downarrow \text { agmatine and } \uparrow \uparrow \uparrow \text { spermine } \\
\text { and spermidine serum levels }\end{array}$ & Lionetto et al. (2021) [27] \\
\hline \multirow{2}{*}{$\mathrm{CM}$} & $\begin{array}{l}\text { } \uparrow \uparrow \uparrow \text { VEF amplitude } \\
\downarrow \downarrow \downarrow \text { VEF habituation }\end{array}$ & Chen et al. (2011) [28] & $\begin{array}{l}\uparrow \uparrow \uparrow \text { activation of hypothalamus after painful } \\
\text { trigeminal stimulus }\end{array}$ & Schulte et al. (2017) [29] & $\begin{array}{l}\text { } \uparrow \uparrow \text { CGRP plasma levels in the } \\
\text { interictal phase }\end{array}$ & $\begin{array}{l}\text { Cernuda-Morollon et al. (2013) } \\
\text { [30] }\end{array}$ \\
\hline & $\begin{array}{l}\uparrow \uparrow \uparrow \text { amplitude of the N2- P2 } \\
\text { LEPs component }\end{array}$ & de Tommaso et al. (2003) [33] & $\begin{array}{l}\downarrow \downarrow \downarrow \text { functional connectivity between the DMN and } \\
\text { the ECN }\end{array}$ & Coppola G. et al. (2019) [34] & $\begin{array}{l}\uparrow \uparrow \uparrow \text { amylin plasma levels in the } \\
\text { interictal phase }\end{array}$ & Irimia at al. (2020) [35] \\
\hline \multirow[b]{3}{*}{$\mathrm{MOH}$} & $\begin{array}{l}\uparrow \uparrow \uparrow \text { amplitude and } \downarrow \downarrow \downarrow \\
\text { habituation of SEP }\end{array}$ & $\begin{array}{l}\text { Srikiatkhachorn et al. (2013) [36] } \\
\text { Coppola et al. (2010) [37] }\end{array}$ & $\downarrow \downarrow \downarrow$ fractional anisotropy of the brain white matter & Shibata et al. (2018) [38] & $\uparrow \uparrow \uparrow$ platelet 5-HT uptake $\left(\mathrm{V}_{\max }\right)$ & Ayzenberg et al. (2008) [39] \\
\hline & $\begin{array}{l}\downarrow \downarrow \downarrow \text { amplitude of MEP in rTMS } \\
\text { at } 5 \mathrm{~Hz}\end{array}$ & Cortese F. et al. (2019) [40] & $\begin{array}{l}\downarrow \downarrow \downarrow \text { PET-FDG metabolism of thalamus, orbitofrontal } \\
\text { cortex, anterior cingulate gyrus, insula/ventral } \\
\text { striatum and right inferior parietal lobule }\end{array}$ & $\begin{array}{l}\text { Srikiatkhachorn et al. (2013) } \\
{[36]}\end{array}$ & $\begin{array}{l}\downarrow \downarrow \downarrow \text { platelet levels of AEA and } \\
2-\mathrm{AG}\end{array}$ & Rossi et al. (2008) [41] \\
\hline & $\begin{array}{l}\quad \downarrow \downarrow \downarrow \text { TST of the NWR } \\
\uparrow \uparrow \uparrow \uparrow \text { amplitude of the NWR }\end{array}$ & Perrotta et al. (2010) [42] & $\begin{array}{l}\text { Altered functional connectivity of nucleus } \\
\text { accumbens and dorsal rostral putamen }\end{array}$ & $\begin{array}{l}\text { Lai et al. (2018) [43] } \\
\text { Torta et al. (2016) [44] }\end{array}$ & $\begin{array}{c}\uparrow \uparrow \uparrow C B 2 \text { protein expression in } \\
\text { PBMCs } \\
\text { PBCs } \\
\text { P个 FAAH gene expression in } \\
\text { PBMCs } \\
\uparrow \uparrow \uparrow \text { NAPE-PLD, MAGL and } \\
\text { DAGL genes expression in } \\
\text { PBMCs }\end{array}$ & Greco et al. (2021) [45] \\
\hline
\end{tabular}

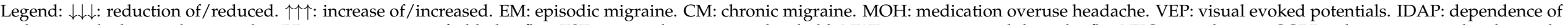

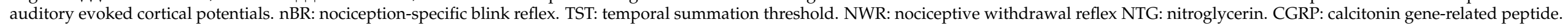

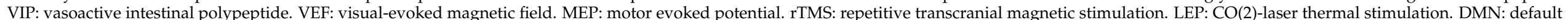

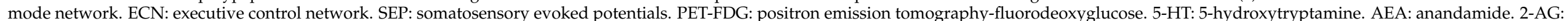
2-acylglycerol. PBMCs: peripheral blood mononuclear cells. NAPE-PLD: N-acylphosphatidylethanolamide-phospholipase D. MAGL: monoacylglycerol lipase. DAGL: diacylglycerol lipase. 


\section{Roles of miR-382-5p and miR-34a-5p in Migraine and Pain}

\section{1. $m i R-382-5 p$ and $m i R-34 a-5 p$ in Migraine}

There is mounting evidence that miR-382-5p and miR-34a-5p are dysregulated in migraine (Tables 2 and 3).

Andersen et al. first detected the aberrant serum expression of $32 \mathrm{miRNAs}$ in migraine patients in 2016 and identified a nine-fold increase in miR-34a-5p expression with a fourfold increase in miR-382-5p expression during the migraine attack when compared to the interictal phase [46]. Intriguingly, they also detected a significant higher miR-382-5p expression in migraine patients during the interictal period when compared to healthy subjects, and thus proposed this miRNA as a possible actor in migraine pathophysiology and a specific biomarker of the disease [46]. A main limitation of the study was that the migraine population was not well characterized, thus it was not possible to correlate the results obtained with the migraine phenotype (episodic or chronic) and with headache features.

A previously suggested hypothesis was that miR-382-5p serum expression was explained by increased blood-brain barrier permeability, which was suggested to occur during the migraine attack in a pre-clinical model [47], but this hypothesis has never been confirmed in humans and needs further confirmation.

Previous studies revealed that both miR-382-5p and miR-34a-5p negatively modulate target genes linked to GABAergic facilitating signaling, a neurotransmitter involved in trigeminal pain analgesia [46]. This may represent a protective compensatory mechanism in migraine self-limitation; indeed, higher GABA levels have been detected in the cerebrospinal fluid and in the saliva during migraine attacks $[48,49]$.

miR-382-5p is also involved in Interleukin (IL)-10 anti-inflammatory signaling, where it acts via a negative modulation of the interleukin 10 receptor alpha subunit (IL-10RA), an endogenous inhibitor of pro-inflammatory IL-1 $\beta$ signaling [46].

The seminal work of Gallelli et al. paved the way for the identification of miRNAs as potential peripheral biological markers of drug response. They demonstrated lower miR-34a-5p and miR-375-5p expression in serum and saliva of children and adolescents treated with magnesium and acute nonsteroidal anti-inflammatory drugs (NSAIDs) compared to untreated subjects with migraine without aura [50]. It is noteworthy that in the first cohort of patients, the expression of these specific miRNAs was comparable to a group of healthy controls [50].

A recent study specifically analyzed miR-382-5p and miR-34a-5p expression in subjects with EM or $\mathrm{CM}$ and $\mathrm{MOH}(\mathrm{CM}-\mathrm{MOH})$ [51]. The authors described a significantly higher interictal expression of miR-34a-5p and miR-382-5p in the plasma of CM-MOH subjects [51]. This analysis detected for the first time the association between specific miRNAs and the migraine phenotype as well as disease severity [51]. Notably, in this study CGRP plasma levels positively correlated with miR-382-5p and miR-34a-5p expression [51].

Although analyzed as a secondary endpoint, miR-382-5p and miR-34a-5p expression was reduced two months after detoxification from acute medications (in-hospital detoxification program), regardless of the clinical outcome [51]. This observation suggests the possibility of a direct role for acute medications in the expression of both miRNAs.

miR-382-5p and miR-34a-5p were also negatively modulated by erenumab, a monoclonal antibody directed against the CGRP receptor, in a population of difficult-to-treat CM patients with and without $\mathrm{MOH}$ [52]. The expression of each miRNA was reduced after three monthly s.c. administrations of erenumab, irrespective of the clinical outcome, which suggests a direct role for CGRP in miRNA regulation [52]. By contrast, central sensitization improved only in migraine patients who responded to erenumab treatment with an at least $30 \%$ reduction in monthly migraine days [52].

\section{2. $m i R-382-5 p$ and miR-34a-5p in Pain and Putative Mechanisms}

miR-34a expression was reported to be altered in several human diseases besides migraine, including osteoarthritis [53,54], Alzheimer's disease [55], cancer [56,57] and 
leukemia [58]. The connection between miR-34a and these pathologies resides in its strong contribution to the regulation of cell cycles and apoptosis, with miR-34a being a major transcriptional target of p53 [59,60]. The involvement of miR-34a in several painful and non-painful conditions clearly suggests that, when considered alone, it cannot represent a migraine-specific biomarker. Nonetheless, it may still play a role as part of a multibiomarker panel signature of migraine [7].

Regarding pain-related disorders, miR-34a plays a role in the modulation of the inflammatory response [61,62]. Upregulation of mir-34a has been reported in osteoarthritic tissues specimens and in patients with low back pain related to intervertebral disc degeneration [63-65]. miR-34a expression was enhanced by IL-1 $\beta$ release [53], although miR-34a itself can up-regulate the IL-1 $\beta$ /cyclooxygenase 2 (COX-2)/Prostaglandin E2 (PEG2) inflammation pathway [66] by targeting the deacetylase silencing information regulator 1 (SIRT1) [66-68]. miR-34a also inhibits SIRT1 by increasing the acetylation of the nuclear factor kappa B (NF-kB) P65 subunit, ultimately enhancing the transcription of inflammatory mediators, including IL-1 $\beta$, IL-6 and tumor necrosis factor- $\alpha$ [67,69]. In an animal model of inflammatory pain, Chen et al. reported an increase in miR-34a expression in the spinal cord and showed that its inhibition by a miR-34a antagonist exerted analgesic effects by increasing spinal SIRT1 expression [68]. The inhibition of SIRT1 was reported to enhance the release of CGRP in rat trigeminal ganglia in vitro, probably as a consequence of IL-1 $\beta /$ COX-2/PGE2 pathway activation [66]. Other genes coding for proteins that are involved in chronic pain pathways have been validated as targets of miR-34a, such as sodium voltage-gated channel beta subunit $2(\mathrm{Scn} 2 \mathrm{~b})$ and vesicle-associated membrane protein 2 (VAMP2) [70]. This latter belongs to the SNARE (soluble N-ethyl-maleimide-sensitive factor attachment protein receptor) protein complex that regulates presynaptic neurotransmitter release as well as neurotransmitter receptor trafficking and synaptic plasticity [71], whose variants have been reported to be linked with migraine susceptibility [72]. It must be noted that miR-34a was found to be down-regulated in rats' dorsal root ganglions 12 days after the experimental induction of neuropathic pain, with the concomitant up-regulation of VAMP2 [70]. Since the increase of synaptic proteins is related to higher glutamate release [73], this may ultimately lead to an enhancement of nociception. Nonetheless, miR-34a was predicted to target the genes coding for specific GABA receptors subunits (GABBR2, Gamma-aminobutyric acid type B receptor subunit 2; GABRA3, Gamma-aminobutyric acid receptor subunit alpha-3) [46]. In this context, an up-regulation of this microRNA, as reported in serum of migraine patients, could contribute to the reduction of the GABA inhibitory signal [46]. Although some controversies exist, it is reasonable to assert that the role of miR-34a may vary across different pain disorders according to the time of evaluation and, more importantly, depending on specimen collection. However, together these observations strongly point towards the contribution of miR-34a to the regulation of pain-related neurotransmission.

Like miR-34a, miR-382-5p was predicted to target the GABRA5 (Gamma-aminobutyric acid receptor subunit alpha-5) GABA receptor subunit and also IL-10RA [46]. Thus, the observed up-regulation in the serum levels of miR-382-5p in migraine patients may be explained by reduced GABAergic and anti-inflammatory signaling [46,74,75]. The increased miR-382-5p serum levels in migraine patients may be also related to high protein levels of transforming growth factor $\beta$ (TGF- $\beta$ ). In agreement with this hypothesis, increased TGF- $\beta$ levels were found in the plasma and cerebrospinal fluid of patients with EM [76,77]. TGF- $\beta$ is able to increase the expression of miR-382-5p [78-80] by inhibiting transcription factors' repressors [81]. TGF- $\beta$ modulated miR-382-5p in vitro (human CD34+ stem cells), resulting in the increased accumulation of reactive oxygen species (ROS). ROS accumulation was explained by miR-382-5p-induced inhibition of superoxide dismutase 2 (SOD2), a direct target of this mRNA $[79,80]$. This latter issue appears to be relevant in the context of migraine pain, since oxidative stress and mitochondrial dysfunction was suggested as actors in migraine pathophysiology [82-84]. miR-382-5p regulation is also influenced by the long non-coding RNA Ftx (lncRNA Ftx), which exerts its action as a competing endogenous 
RNA (ceRNA), competing with miR-382-5p at targets level [85]. An increase in miR-382-5p expression together with a down-regulation of lncRNA Ftx and neuregulin-1 (Nrg-1) was reported in an animal model of neuropathic pain [85]. The lack of inhibition exerted by lncRNA Ftx on miR-382, is supposed to increase the inhibition of Nrg-1, thus facilitating pain and inflammation [85]. The involvement of Nrg-1 in pain was also reported in an animal model of inflammatory pain. Its reduction has been found in the dorsal root ganglia and spinal cord of mice, contributing to hypersensitivity [86]. Notably, increasing Nrg-1 expression facilitates analgesia and tissue repair by modulating glial cells proliferation, central nervous system injury repair and the reduction of the release of pro-inflammatory cytokine [85,87-89]. Increased miR-382-5p expression in pain conditions may also be related to nuclear factor kappa B (NF- $\mathrm{kB}$ ) signaling, implicated in migraine pain [90-92]. NF- $k B$ acts as a transcription factor for many miRNAs [93], including miR-382 [94]. Indeed, the inhibition of NF-kB significantly suppressed miR-382 in vitro [94].

Table 2. Current evidence on miRNA expression in migraine.

\begin{tabular}{|c|c|c|c|c|}
\hline miRNA & Specimen & Population & Summary of Study Results & Reference \\
\hline \multirow[t]{3}{*}{$\operatorname{miR}-382-5 p$} & Serum & $\begin{array}{l}8 \text { migraine patients without } \\
\text { any medication } \\
12 \text { migraine patients with } \\
\text { normal medication habits }\end{array}$ & $\begin{array}{l}\text { 4.1-fold increase expression during } \\
\text { migraine attack. } \\
\text { Higher expression during the } \\
\text { interictal period in migraine patients }\end{array}$ & $\begin{array}{l}\text { Andersen et al. } \\
\text { (2016) [46] }\end{array}$ \\
\hline & Peripheral blood & 27 patients with EM & Higher levels in CM-MOH vs. EM. & Greco et al. (2020) \\
\hline & mononuclear cells & 28 patients with $\mathrm{CM}-\mathrm{MOH}$ & Positive correlation with CGRP levels. & {$[51]$} \\
\hline \multirow[t]{3}{*}{$\operatorname{miR}-34 a-5 p$} & Serum & $\begin{array}{l}8 \text { migraine patients without } \\
\text { any medication } \\
12 \text { migraine patients with } \\
\text { normal medication habits }\end{array}$ & $\begin{array}{l}\text { 9-fold increase expression during } \\
\text { migraine attack. }\end{array}$ & $\begin{array}{l}\text { Andersen et al. } \\
\text { (2016) [46] }\end{array}$ \\
\hline & Peripheral blood & & Higher levels in $\mathrm{CM}-\mathrm{MOH}$ vs. EM. & Greco et al. (2020) \\
\hline & mononuclear cells & with $\mathrm{CM}-\mathrm{MOH}$ & Positive correlation with CGRP levels. & [51] \\
\hline \multirow[t]{2}{*}{ miR-30a } & Serum & $\begin{array}{l}\text { Patients with migraine with or } \\
\text { without aura (sample size not } \\
\text { defined) }\end{array}$ & $\begin{array}{c}\text { Significant lower expression in } \\
\text { patients with migraine vs. healthy } \\
\text { controls. }\end{array}$ & $\begin{array}{l}\text { Zhai et al. (2018) } \\
\qquad \text { [93] }\end{array}$ \\
\hline & $\begin{array}{l}\text { Peripheral blood } \\
\text { mononuclear cells }\end{array}$ & $\begin{array}{l}15 \text { female patients with } \\
\text { migraine without aura } \\
13 \text { healthy controls }\end{array}$ & $\begin{array}{c}\text { Reduced miR-181a, let-7b and miR-22 } \\
\text { levels in EM vs. HC. } \\
\text { Increased miR-27b levels in EM vs. } \\
\text { HC. }\end{array}$ & $\begin{array}{l}\text { Tafuri et al. (2015) } \\
\text { [94] }\end{array}$ \\
\hline \multirow[t]{2}{*}{$\begin{array}{l}\text { Other } \\
\text { miRNAs }\end{array}$} & Serum & $\begin{array}{l}8 \text { migraine patients without } \\
\text { any medication } \\
12 \text { migraine patients with } \\
\text { normal medication habits } \\
8 \text { healthy controls }\end{array}$ & $\begin{array}{l}\text { Increased miR-29c-5p and miR-26b-3p } \\
\text { expression in EM patients. }\end{array}$ & $\begin{array}{l}\text { Andersen et al. } \\
\text { (2016) [46] }\end{array}$ \\
\hline & Serum & $\begin{array}{l}30 \text { patients with EM } \\
30 \text { healthy controls }\end{array}$ & $\begin{array}{l}\text { Increased expression of miR-155, } \\
\text { miR-126, and let-7 in EM vs. HC. }\end{array}$ & $\begin{array}{c}\text { Chen et al. (2018) } \\
\text { [95] }\end{array}$ \\
\hline
\end{tabular}

Legend: EM: episodic migraine. CM: chronic migraine. MOH: medication overuse headache. HC: healthy controls. CGRP: calcitonin gene-related peptide. 
Table 3. Treatment driven modifications of miRNAs expression in migraine.

\begin{tabular}{|c|c|c|c|c|}
\hline Treatment & Posology and Duration & Population & miRNAs Modifications and Timing & Reference \\
\hline Detoxification & $\begin{array}{l}\text { 7-day standardized detoxification protocol in } \\
\text { hospitalized patients: abrupt withdrawal of } \\
\text { overused drugs associated to intravenous } \\
\text { therapy twice daily with isotonic } 0.9 \% \mathrm{NaCl} \\
\text { saline } 500 \mathrm{~mL}+\text { cyanocobalamin } 2500 \mathrm{mcg}+\text { folic } \\
\text { acid } 0.70 \mathrm{mg} \text { + nicotinamide } 12 \mathrm{mg}+\text { ascorbic } \\
\text { acid } 150 \mathrm{mg}+\text { sodic glutathione } 600 \mathrm{mg}+ \\
\text { delorazepam } 0.5 \mathrm{mg}\end{array}$ & 28 patients with $\mathrm{CM}-\mathrm{MOH}$ & $\begin{array}{l}\text { Significant reduction of miR-382-5p and } \\
\text { miR-34a-5p two months after } \\
\text { detoxification in CM-MOH. }\end{array}$ & Greco et al. (2020) [51] \\
\hline Erenumab $70 \mathrm{mg}$ & $\begin{array}{l}\text { One administration s.c. every } 28 \text { days for a total } \\
\text { of three administrations }\end{array}$ & $\begin{array}{c}7 \text { patients with } \mathrm{CM} \\
33 \text { patients with } \mathrm{CM}-\mathrm{MOH}\end{array}$ & $\begin{array}{l}\text { Reduction of miR-382-5p and miR-34a-5p } \\
\text { in the overall study population after three } \\
\text { months of treatment with erenumab. } \\
\text { No differences between } 30 \% \text { Responders } \\
\text { and NON-responders after three months } \\
\text { of erenumab treatment. }\end{array}$ & De Icco et al. (2020) [52] \\
\hline $\begin{array}{l}\text { NSAIDs and long-term } \\
\text { magnesium }\end{array}$ & $\begin{array}{l}\text { Chronic treatment with magnesium }(400 \mathrm{mg} / \text { day } \\
\text { for three months })+ \text { Abortive treatment with } \\
\text { acetaminophen }(15 \mathrm{mg} / \mathrm{kg}) \text { or ibuprofen } \\
(10 \mathrm{mg} / \mathrm{kg})\end{array}$ & $\begin{array}{l}24 \text { children and adolescents affected } \\
\text { by migraine without aura divided } \\
\text { into two groups (treated, and } \\
\text { untreated) and } 12 \text { healthy controls }\end{array}$ & $\begin{array}{c}\text { Decreased expression of miR-34a-5p in } \\
\text { migraine patients treated with NSAIDs } \\
\text { and long-term magnesium vs. untreated } \\
\text { migraine patients. } \\
\text { Decreased expression in healthy controls } \\
\text { vs. untreated migraine patients. } \\
\text { Comparable expression between migraine } \\
\text { patients treated with NSAIDs and } \\
\text { long-term magnesium and healthy } \\
\text { controls. }\end{array}$ & Gallelli et al. (2019) [50] \\
\hline Biphasic ketogenic diet & $\begin{array}{l}\text { Phase 1: } 3 \text { weeks with }<30 \mathrm{~g} \text { of carbohydrates } \\
\text { Phase 2: } 3 \text { weeks with }<120 \mathrm{~g} \text { of carbohydrates }\end{array}$ & $\begin{array}{l}6 \text { female obese patients with } \\
\text { migraine }\end{array}$ & $\begin{array}{l}\text { Reduction of has-miR-590-5p and } \\
\text { has-miR-660-3p expression after a 6-week } \\
\text { ketogenic diet }\end{array}$ & Cannataro et al. (2020) [96] \\
\hline
\end{tabular}

Legend: CM: chronic migraine. MOH: medication overuse headache. CGRP: calcitonin gene-related peptide. NSAIDs: nonsteroidal anti-inflammatory drugs. 
These observations suggest that the activation of the inflammatory pathways may lead to an up-regulation of miR-34a and miR-382 which in turn modulate the release of inflammatory and pain mediators (Figure 1).

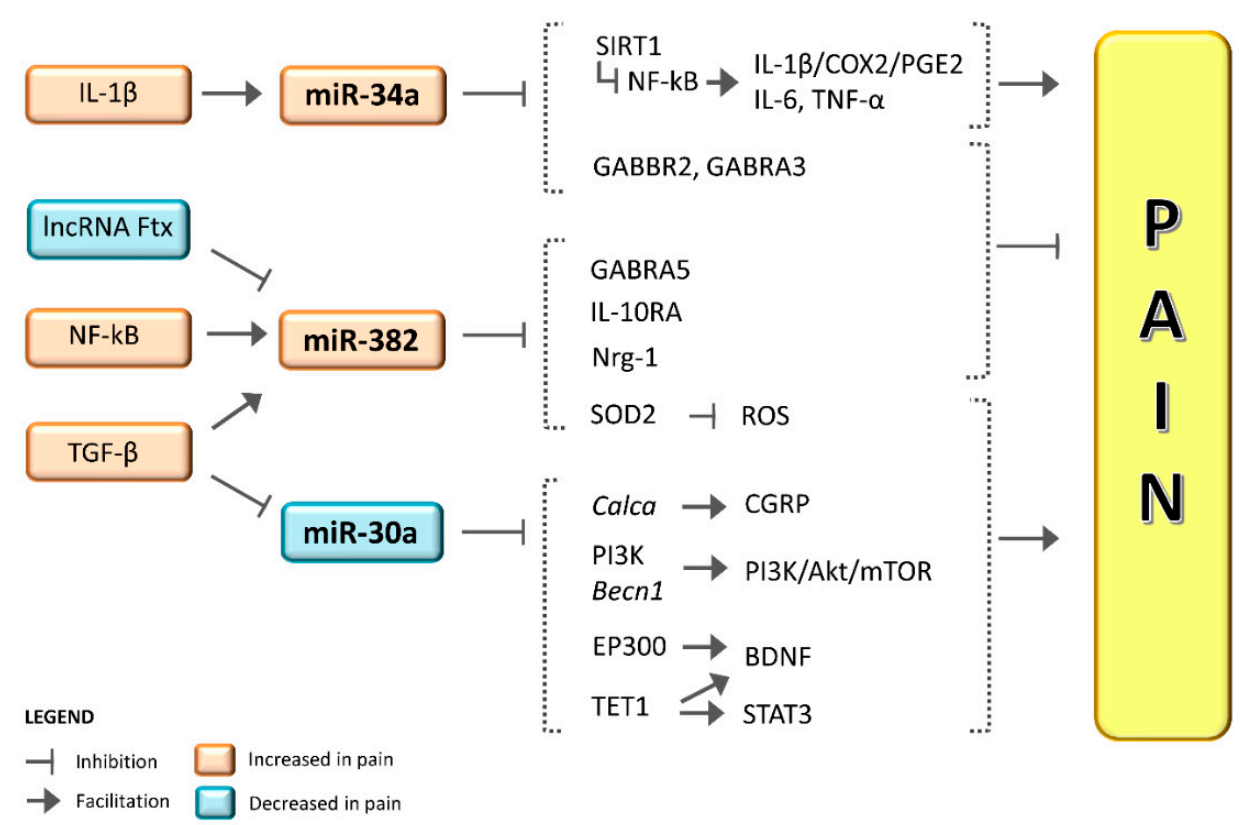

Figure 1. Schematic representation of putative mechanisms through which miR-34a, miR-382 and miR-30a interfere with pain. Legend: in pain conditions, miR-34a and miR-382 were upregulated, while miR30a expression was downregulated. Other molecules are also implicated in the inhibition or enhancement of miRNA expression in pain disorders. The physiological activity of miRNAs is the downregulation of target mRNAs, thus the final effects depend on the role of the mRNAs involved. High levels of miR-34a and miR-382 promote the inhibition of pathways that reduce pain (e.g., GABA signaling). These miRNAs may also downregulate up-stream gene regulators, which in physiological conditions would have blocked pain pathways (e.g., SIRT1). The downregulation of miR30a in pain conditions leads to a reduction of its inhibitory effects. This would lead to an increase in pain-related pathways, since miR-30a targets genes that facilitate pain (like Calca). miRNA = microRNA; mRNA = messenger RNA; BDNF = brain-derived neurotrophic factor; Becn1 = Beclin 1 gene; Calca $=$ Calcitonin related polypeptide alpha gene; $\mathrm{CGRP}=$ calcitonin gene-related peptide; $\mathrm{COX}-2=$ cyclooxygenase 2 ; EP300 = E1A Binding Protein P300; GABBR2 = Gamma-aminobutyric acid type B receptor subunit 2; GABRA3 = Gammaaminobutyric acid receptor subunit alpha-3; GABRA5 = Gamma-aminobutyric acid receptor subunit alpha-5; IL-10RA = interleukin 10 receptor alpha subunit; IL-1 $\beta=$ Interleukin $1 \beta$; IL-6 = Interleukin 6; lncRNA Ftx = long non-coding RNA Ftx; NF- $\mathrm{KB}$ = nuclear factor kappa B; Nrg-1 = neuregulin-1; PGE2 = Prostaglandin E2; PI3K = phosphatidyl Inositol 3-kinase; ROS = reactive oxygen species; Scn $2 b=$ voltage-gated channel beta subunit $2 ;$ SIRT1 = silencing information regulator 1 ; SNARE = soluble N-ethyl-maleimide-sensitive factor attachment protein receptor; SOD2 = superoxide dismutase 2; STAT3 $=$ Signal transducer and activator of transcription 3 ; TET1 = ten-eleven translocation methylcytosine dioxygenase 1 ; TGF- $\beta$ $=$ Transforming growth factor $\beta$; TNF- $\alpha=$ tumor necrosis factor- $\alpha$; VAMP2 $=$ vesicle-associated membrane protein 2.

\section{Role of miR-30a in Migraine and Pain}

Like many other miRNAs, miR-30a can target several different genes [97-100], of which many are connected with pathways related with pain transmission/modulation. Zhai and Zhu reported lower serum miR-30a levels in migraine patients compared to healthy subjects [93] (Tables 2 and 3). Interestingly, the authors also showed that miR-30a overexpression can degrade calcitonin/alpha-CGRP (Calca) gene in vitro, thus reducing CGRP levels [93].

TGF- $\beta$ is known to downregulate miR-30a [101,102]. Given that high protein levels of TGF- $\beta$ were found in migraine patients $[74,75]$, it is worth speculating that, in contrast to what happens with miR-382, the increased TGF- $\beta$ levels might negatively regulate miR-30a expression. This would lead to increased Calca expression and, consequently, to augmented 
CGRP levels. This pathway appears to be relevant for migraine, as it was hypothesized that Calca degradation may represent a protective mechanism in migraine progression [93].

In line with the above-mentioned observation, low levels of miR-30a were also found in animal models of neuropathic pain $[103,104]$. The involvement of miR-30a in pain modulation resides in its ability to regulate different pathways contributing to pain. For instance, miR-30a directly binds phosphatidyl Inositol 3-kinase (PI3K) [105] and Becn1 [106], the gene coding for Beclin 1, a core subunit of the PI3K complex. Up-regulation of miR-30a inhibits the PI3K/Akt/mTOR signaling pathway, thus resulting in a reduced central sensitization and pain relief [107-109]. In addition, miR-30a targets ten-eleven translocation methylcytosine dioxygenase 1 (TET1) [110], which is involved in the DNA demethylation of some genes linked to pain hypersensitivity, like brain-derived neurotrophic factor (BDNF) [111,112]. Accordingly, miR-30a levels were also found to be reduced in rats with spinal cord injuries, thus confirming the hypothesis that miR-30a may have a protective role when it comes to neuropathic pain [104].

Taken together, these findings support the role of miR-30a in pain modulation and suggest that a down-regulation of miR-30a in pain conditions may lead to an up-regulation of different pro-nociceptive effectors possibly involved in migraine pain. The overexpression of miR-30a may be a useful pathway to counteract pain in general and possibly also in migraine pain (Figure 1).

\section{Role of Other miRNAs in Migraine and Pain}

Recently, the micro-MIG study corroborated the hypothesis that the expression of different miRNA expression is altered in EM and CM when compared to a control group, although no specific miRNAs were identified [113].

Furthermore, differential expressions of miRNAs were reported in the serum and in circulating blood monocytes of people with migraine without aura compared to healthy controls. These alterations were predominantly represented by the downregulation of miR-181a, let-7b and miR-22, with only miR-27b found to be upregulated. Interestingly, the altered expression of these aforementioned miRNAs has been linked to a higher cardiovascular risk, potentially correlating with the well-known relationship between migraine and vascular dysfunction [94]. Along with miR-382-5p and miR-34a-5p, Andersen and co-workers also found increased levels of miR-29c-5p and miR-26b-3p in EM patients, suggesting a further dysregulation of GABAergic and interleukin (IL4 and IL1RA) signaling [46].

A subsequent in-depth analysis supported the link between migraine and endothelial dysfunction, demonstrating an altered expression of miRNAs related with endothelial function (miR-155, miR-126 and let-7) in EM patients without vascular risk factors when compared to healthy subjects [95].

Burstein et al. described alteration of up to 27 miRNAs in the periosteum of CM patients when compared to healthy controls [114]. These alterations led to an upregulated expression of 25 genes involved in inflammatory response and a downregulation in 11 genes involved in the opposite task [114].

A recent review suggested that migraine and major depression may share a similar mRNAs profile [115]. Indeed, among 12 miRNAs previously studied in migraine, 11 were also altered in depressive disorders. This observation further suggests caution in interpreting these miRNAs as single migraine-specific biomarkers [115].

Several miRNAs were studied during celecoxib administration [116]. miR-590-5p, in particular, appears a to be a target as it is specifically dysregulated in humans during migraine attack, in subjects with Complex Regional Pain syndrome and in mice with experimentally-induced chronic pain conditions [116].

More recently, a significant reduction in miR-375 expression, a specific miRNA related to cancer, metabolic and inflammatory diseases [117], was identified in the serum and saliva of migraine children taking symptomatic (NSAIDs) and preventive (long-term magnesium) drugs [50]. 
Finally, there is evidence of miRNA variation related to non-drug interventions, as suggested by the alteration in has-miR-590-5p and has-miR-660-3p expression induced by a 6-week ketogenic diet [96]. The precise biochemical mechanisms underlying this phenomenon are elusive, but the Authors invoked the antioxidant and antiinflammatory effects of the diet, together with the restoration of a physiological cortical excitability $[118,119]$.

It is worth reporting that negative results failing to confirm changes in miRNA expression in migraine patients have also been published, with the main limitation generally represented by low sample sizes and limited statistical power [120].

A deep analysis of the role of miRNAs in non-migraine pain conditions is beyond the scope of the present review, but some of the clinical and preclinical findings derived from studies on pain may indirectly and effectively delineate the relationship between miRNA expression and migraine. In recent years, various pain models, such as inflammatory, neuropathic or diabetic pain models have included the evaluation of miRNAs [121]. Depending on the study conducted, both overexpression and suppression were reported in association with pain exacerbation [122]. miRNA expression varied across studies depending on the tissue specimen, the site of the nociceptive pathway evaluated and the time of collection after the experimental injury, thus showing a time and space-dependent expression [123-126]. In mice models of peripheral nerve injury, miR-21 was found consistently increased across various studies [127-130]. Bai et al. injected the complete Freund's adjuvant (CFA) in the masseter muscle of rats and subsequently analyzed the ipsilateral trigeminal ganglion specimen. They found that several miRNAs (miR-29a, miR-99, miR-124a and miR-134) were downregulated in the following hours, with a subsequent upregulation rebound days after the injection [123].

Regarding space-dependent expression, Kusuda et al. found a downregulation of miR-1, miR-16 and miR-206 in the dorsal roots of rats injected with CFA in the left hind paw. By contrast, concomitant analysis of the spinal dorsal horn showed a tardive upregulation of the same set of miRNAs [125].

These findings are consistent with the tissue-specific action of miRNAs involved in pain modulations, suggesting that the same miRNA may differently influence gene expression depending on the tissue specimen.

Human studies have focused primarily on detecting circulating miRNAs in cohorts of patients affected by chronic pain conditions, such as fibromyalgia, complex regional pain syndromes, inflammatory and irritable bowel syndromes, osteoarthritis and others. Given the large number of heterogeneous studies, only a fraction of findings has been consistently confirmed [131]. In fibromyalgia, the severity of pain inversely correlated with miR-320 and miR-145 levels [132,133]. A reduced expression of miR-320 was associated with chronic pain development in a cohort of patients who experienced motor vehicle collisions [134]. A consistent finding in studies investigating osteoarthritic pain is the general upregulation of miR-146, an alteration that was normalized by successfully treatment with balneotherapy [135].

miRNA expression was also explored as a possible diagnostic biomarker of pain disorders [129]. For instance, Dayer et al. proposed miR-320 and miR-98-5p as possible biomarkers for distinguishing neuropathic from non-neuropathic pain conditions [136].

Finally, there is increasing evidence from animal models of the potential role of miRNAs as a therapeutic target.

As previously mentioned, treatment with a miR-34a antagonist was effective in inducing analgesia in a rodent model of inflammatory pain induced by CFA $[68,70]$. Similarly, many other mimics or inhibitors of different miRNAs have been tested in several animal models of pain, proving their effectiveness [137,138].

There are currently several therapeutic strategies (polymeric vectors, lipid-based delivery systems, viral vectors) under consideration for both increasing and decreasing specific miRNA expression in selected tissues [139,140]. Some crucial aspects are yet to be addressed, namely the necessity to find vectors able to safely cross the blood-brain barrier, 
the evaluation of the drug-related toxicity and the ability to selectively target specific miRNAs to reduce the interaction with other genes not related to the target disease.

\section{Discussion}

Migraine represents a leading cause of disability, affecting young and adult people during the most productive years of their life. It also imposes an enormous economic burden on the society, mainly attributed to indirect related costs, such as work presenteeism and absenteeism.

Novel drug therapies modulating the CGRP pathways are now available, but their high cost and the presence of resistant patients imposes the need to continue research on novel therapeutic targets as well as on specific predictive biomarkers. Several biological and instrumental evaluations were suggested as potential migraine biomarkers, including genetic profiles, plasma and CSF neurotransmitters (CGRP, PACAP, VIP, glutamate), cytokines and neuroimaging alterations [7]. Although promising, none of these may truly be considered a solid biomarker, and further confirmation studies are needed. miRNAs have attracted the attention of the scientific community, initially to better understand the epigenetic impact of several physiological processes and, more recently, as possible diagnostic, monitoring and predictive biomarkers in a broad spectrum of pain and non-pain conditions. The data from the literature summarized here suggest that miRNAs may well have a place in the network of pathophysiological alterations that reflect the complexity of migraine.

Validated biological biomarkers may allow several steps forward in the management of migraine and primary headaches: (i) the refinement of the diagnosis according to biological features; (ii) the prediction of the response to advanced therapies; (iii) the improved selection of patients for clinical trials or in everyday practice; (iv) the identification of novel molecular targets for drugs development. Recent but increasing evidence suggests a role for miR-382-5p, miR-34a-5p and miR-30a in migraine.

These miRNAs are associated with migraine phenotypes and disease severity as suggested by their expression in peripheral blood mononuclear cells of EM or CM-MOH patients [51]. Notably, the association between miRNAs levels and the migraine phenotypes survived a multivariate correction for age, sex, disease duration and CGRP levels. Furthermore, miR-382-5p and miR-34a-5p expression in peripheral blood mononuclear cells of subjects of these two clinical populations positively correlated with CGRP plasma levels. In this context, it is worth mentioning that an increased expression of both miRNAs was also reported in a population of difficult-to-treat $\mathrm{CM}$ patients with and without medication overuse [52]. Collectively, these findings support a role for miR-382-5p and miR-34a-5p in migraine, which is partly, but probably not entirely, related to the interaction with the CGRP pathway.

Data from our group suggest that the expression of miR-382-5p and miR-34a-5p may be influenced by migraine treatments. Indeed, detoxification from overused acute drugs and migraine preventive treatment with erenumab negatively modulated the expression of both miRNAs [51,52]. Interestingly this biological effect was independent of the clinical outcome and of the reduction in central sensitization observed in erenumab responders. Accordingly, the baseline expression of miR-382-5p and miR-34a-5p was not capable of predicting the clinical response to erenumab. Although these observations seem to limit the clinical utility of these miRNAs for the prediction and monitoring of drug response, if confirmed, they will definitely provide a new perspective on the pathophysiological investigations of migraine mechanisms based on a more sophisticated subtyping of the large migraine population. Notably, Christensen et al. suggested that migraine responders to erenumab were characterized by a specific CGRP-phenotype, including: (i) an increased migraine-like induction rate to CGRP administration; (ii) a more severe headache during the induction test; and (iii) a long-lasting headache produced by CGRP administration [141].

Interestingly, another link between CGRP and miRNAs was recently reported by Zhai and Zhu [93]. They found reduced levels of miR-30a in migraine patients, a miRNA 
postulated to negatively modulate the gene coding for CGRP. Thus, miR-30a agonism may also represent an interesting novel therapeutic target for migraine.

The identification of single disease-specific biomarkers represents a priority of researchers operating in the migraine field.

Thus far, the available evidence on the possible role of migraine biomarkers for miR-382-5p, miR-34a-5p and miR-30a is compelling, although not entirely convincing. These molecules are involved in different ways in several processes and diseases related with pain, with a certain degree of complementary and synergic effects. Thus, it seems reasonable to hypothesize that in the future these miRNAs may qualify as part of a multibiomarkers panel signature of migraine, rather than as individual biomarkers. Such a panel will hopefully contribute to the possibility of identifying distinct phenotypes across the migraine spectrum, and ideally it will also help to predict responses to different treatments.

Finally, miRNAs modulation with pharmacological agonists ("agomir") and antagonists ("antagomir") has already been tested in non-migraine pre-clinical and clinical conditions. For instance, antagomirs targeting miR-27b, miR-107 and miR-155 as well as agomirs targeting miR-126 and miR-195 were tested in pre-clinical models of ischemic stroke, with promising pre-clinical results [142]. A miR-34a antagomir also produced analgesic effects in a pre-clinical pain model of the spinal cord [68]. In a phase 1 study, a miR-34a agonist was tested for safety and tolerability in patients with solid neoplasms. A dose-dependent modulation of target genes was demonstrated in white blood cells, but the trial was terminated early due to serious, immune-mediated, adverse events [143]. Constant drug development will hopefully lead to novel second generation miRNAs agomirs and antagomirs with improved safety profiles.

Several unanswered questions call for further research aimed at disentangling the characteristics and direction of the relationship between miRNAs and migraine.

Moreover, it is reasonable to state that miRNAs are involved in other primary and secondary headaches, such as tension-type headache, trigeminal autonomic cephalalgias, and post-traumatic headache. Finally, further investigations are needed to confirm the association between different migraine phenotypes and miRNAs expression.

\section{Conclusions}

The initial evidence prompts a possible role for miRNA profiling in migraine research. Clinical data on miR-382-5p, miR-34a-5p and miR-30a seem promising, but their scientific strength is limited by the lack of consistency across studies due to: (i) inhomogeneity or poor definition of migraine cohorts (EM, CM with and without $\mathrm{MOH})$ and related comorbidities, (ii) small sample sizes and (iii) different types of specimens (e.g., blood, saliva, CSF) collected for miRNAs analysis. Further studies are therefore needed to confirm and expand on the role of miRNAs in migraine pathophysiology and management.

In the future, it will be important to tackle the different components of migraine in their dynamic manifestations. Indeed, migraine is a complex disorder characterized by recurring attacks, each defined by a sequence of phases: a prodromal phase, a pain phase either preceded or not by aura symptoms and a postdrome phase. The prodromal and postdrome phases have attracted the attention of the scientific community as they may represent the true timeframe for the study of the mechanisms involved in the origin and cessation of the migraine attack.

The availability of reliable and validated human migraine models will facilitate the study of miRNA expression in the different phases of the migraine cycle, prompting the possibility to set experimentally controlled conditions.

Author Contributions: L.A., C.D. and R.D.I.: paper concept and design, preparation of the first draft of the manuscript, final revision of the manuscript for important intellectual content. C.D., M.C., G.V. and E.M.P.: bibliographic research, preparation of the first draft of the manuscript, final revision of the manuscript for important intellectual content. M.A., A.M.Z., R.G. and C.T.: paper concept and design, interpretation of data, final revision of the manuscript for important intellectual content. All authors have read and agreed to the published version of the manuscript. 
Funding: This paper was supported by a grant from the Italian Ministry of Health to IRCCS Mondino Foundation, Pavia, Italy ("Ricerca Finalizzata: GR-2016-02363848").

Institutional Review Board Statement: Not applicable.

Informed Consent Statement: Not applicable.

Data Availability Statement: Not applicable.

Acknowledgments: The authors thank the Research Nurses and the entire team of the Headache Science \& Neurorehabilitation Center of the IRCCS Mondino Foundation for their invaluable assistance in all activities.

Conflicts of Interest: L.A., C.D., M.C., G.V., E.M.P., M.A., A.M.Z., R.G. and R.D.I. have no conflicts of interest to declare. C.T. received honoraria for the participation in advisory boards or for oral presentations from: Allergan, ElectroCore, Eli-Lilly, Novartis and Teva. C.T. has no ownership interest and does not own stocks of any pharmaceutical company. C.T. serves as Chief Section Editor of Frontiers in Neurology-Section Headache Medicine and Facial Pain and on the editorial board of The Journal of Headache and Pain.

\section{References}

1. Headache Classification Committee of the International Headache Society (IHS). The International Classification of Headache Disorders, 3rd edition. Cephalalgia 2018, 38, 1-211. [CrossRef]

2. Abbafati, C.; Abbas, K.M.; Abbasi-Kangevari, M.; Abd-Allah, F.; Abdelalim, A.; Abdollahi, M.; Abdollahpour, I.; Abegaz, K.H.; Abolhassani, H.; Aboyans, V.; et al. Global burden of 369 diseases and injuries in 204 countries and territories, 1990-2019: A systematic analysis for the Global Burden of Disease Study 2019. Lancet 2020, 396, 1204-1222. [CrossRef]

3. Buse, D.C.; Rupnow, M.F.T.; Lipton, R.B. Assessing and Managing All Aspects of Migraine: Migraine Attacks, Migraine-Related Functional Impairment, Common Comorbidities, and Quality of Life. Mayo Clin. Proc. 2009, 84, 422-435. [CrossRef]

4. Berra, E.; Sances, G.; De Icco, R.; Avenali, M.; Berlangieri, M.; De Paoli, I.; Bolla, M.; Allena, M.; Ghiotto, N.; Guaschino, E.; et al. Cost of Chronic and Episodic Migraine: A pilot study from a tertiary headache centre in northern Italy. J. Headache Pain 2015, 16, 50. [CrossRef]

5. Tassorelli, C.; Jensen, R.; Allena, M.; De Icco, R.; Sances, G.; Katsarava, Z.; Lainez, M.; Leston, J.A.; Fadic, R.; Spadafora, S.; et al. A consensus protocol for the management of medication-overuse headache: Evaluation in a multicentric, multinational study. Cephalalgia 2014, 34, 645-655. [CrossRef] [PubMed]

6. Burstein, R.; Noseda, R.; Borsook, D. Migraine: Multiple processes, complex pathophysiology. J. Neurosci. 2015, 35, 6619-6629. [CrossRef]

7. Ashina, M.; Terwindt, G.M.; Al-Karagholi, M.A.M.; de Boer, I.; Lee, M.J.; Hay, D.L.; Schulte, L.H.; Hadjikhani, N.; Sinclair, A.J.; Ashina, H.; et al. Migraine: Disease characterisation, biomarkers, and precision medicine. Lancet 2021, 397, 1496-1504. [CrossRef]

8. Ashina, M. Migraine. N. Engl. J. Med. 2020, 383, 1866-1876. [CrossRef]

9. Gazerani, P. Current Evidence on Potential Uses of MicroRNA Biomarkers for Migraine: From Diagnosis to Treatment. Mol. Diagn. Ther. 2019, 23, 681-694. [CrossRef] [PubMed]

10. Tana, C.; Giamberardino, M.A.; Cipollone, F. microRNA profiling in atherosclerosis, diabetes, and migraine. Ann. Med. 2017, 49, 93-105. [CrossRef]

11. O'Brien, J.; Hayder, H.; Zayed, Y.; Peng, C. Overview of microRNA biogenesis, mechanisms of actions, and circulation. Front. Endocrinol. 2018, 9, 402. [CrossRef]

12. Lim, L.P.; Lau, N.C.; Weinstein, E.G.; Abdelhakim, A.; Yekta, S.; Rhoades, M.W.; Burge, C.B.; Bartel, D.P. The microRNAs of Caenorhabditis elegans. Genes Dev. 2003, 17, 991-1008. [CrossRef] [PubMed]

13. Mens, M.M.J.; Ghanbari, M. Cell Cycle Regulation of Stem Cells by MicroRNAs. Stem Cell Rev. Rep. 2018, 14, 309-322. [CrossRef] [PubMed]

14. Makarova, J.A.; Shkurnikov, M.U.; Wicklein, D.; Lange, T.; Samatov, T.R.; Turchinovich, A.A.; Tonevitsky, A.G. Intracellular and extracellular microRNA: An update on localization and biological role. Prog. Histochem. Cytochem. 2016, 51, 33-49. [CrossRef] [PubMed]

15. Condrat, C.E.; Thompson, D.C.; Barbu, M.G.; Bugnar, O.L.; Boboc, A.; Cretoiu, D.; Suciu, N.; Cretoiu, S.M.; Voinea, S.C. miRNAs as Biomarkers in Disease: Latest Findings Regarding Their Role in Diagnosis and Prognosis. Cells 2020, 9, 276. [CrossRef]

16. Costa, C.; Teodoro, M.; Rugolo, C.A.; Alibrando, C.; Giambò, F.; Briguglio, G.; Fenga, C. MicroRNAs alteration as early biomarkers for cancer and neurodegenerative diseases: New challenges in pesticides exposure. Toxicol. Rep. 2020, 7, 759-767. [CrossRef] [PubMed]

17. Peter, M.E. Targeting of mRNAs by multiple miRNAs: The next step. Oncogene 2010, 29, 2161-2164. [CrossRef] [PubMed]

18. Ambrosini, A.; Kisialiou, A.; Coppola, G.; Finos, L.; Magis, D.; Pierelli, F.; Schoenen, J. Visual and auditory cortical evoked potentials in interictal episodic migraine: An audit on 624 patients from three centres. Cephalalgia 2017, 37, 1126-1134. [CrossRef] [PubMed] 
19. Ashina, S.; Bentivegna, E.; Martelletti, P.; Eikermann-Haerter, K. Structural and Functional Brain Changes in Migraine. Pain Ther. 2021, 10, 211-223. [CrossRef]

20. Fusayasu, E.; Kowa, H.; Takeshima, T.; Nakaso, K.; Nakashima, K. Increased plasma substance P and CGRP levels, and high ACE activity in migraineurs during headache-free periods. Pain 2007, 128, 209-214. [CrossRef]

21. Di Clemente, L.; Coppola, G.; Magis, D.; Fumal, A.; De Pasqua, V.; Di Piero, V.; Schoenen, J. Interictal habituation deficit of the nociceptive blink reflex: An endophenotypic marker for presymptomatic migraine? Brain 2007, 130, 765-770. [CrossRef]

22. Perrotta, A.; Anastasio, M.G.; De Icco, R.; Coppola, G.; Ambrosini, A.; Serrao, M.; Sandrini, G.; Pierelli, F. Frequency-Dependent Habituation Deficit of the Nociceptive Blink Reflex in Aura With Migraine Headache. Can Migraine Aura Modulate Trigeminal Excitability? Headache 2017, 57, 887-898. [CrossRef]

23. Palm-Meinders, I.H.; Koppen, H.; Terwindt, G.M.; Launer, L.J.; Konishi, J.; Moonen, J.M.E.; Bakkers, J.T.N.; Hofman, P.A.M.; Van Lew, B.; Middelkoop, H.A.M.; et al. Structural brain changes in migraine. JAMA -J. Am. Med. Assoc. 2012, 308, $1889-1897$. [CrossRef] [PubMed]

24. Cernuda-Morollón, E.; Martínez-Camblor, P.; Alvarez, R.; Larrosa, D.; Ramón, C.; Pascual, J. Increased VIP levels in peripheral blood outside migraine attacks as a potential biomarker of cranial parasympathetic activation in chronic migraine. Cephalalgia 2015, 35, 310-316. [CrossRef] [PubMed]

25. De Icco, R.; Perrotta, A.; Grillo, V.; Cosentino, G.; Sances, G.; Sandrini, G.; Tassorelli, C. Experimentally induced spinal nociceptive sensitization increases with migraine frequency: A single-blind controlled study. Pain 2020, 161, 429-438. [CrossRef]

26. Schulte, L.H.; May, A. The migraine generator revisited: Continuous scanning of the migraine cycle over 30 days and three spontaneous attacks. Brain 2016, 139, 1987-1993. [CrossRef] [PubMed]

27. Lionetto, L.; Guglielmetti, M.; Cipolla, F.; Bernardini, S.; Koehler, B.E.; Capi, M.; De Bernardini, D.; Curto, M.; Manetti, R.; Nicoletti, F.; et al. Polyamines serum levels in episodic and chronic migraine. Expert Rev. Neurother. 2021, 21, 249-254. [CrossRef]

28. Chen, W.T.; Wang, S.J.; Fuh, J.L.; Lin, C.P.; Ko, Y.C.; Lin, Y.Y. Persistent ictal-like visual cortical excitability in chronic migraine. Pain 2011, 152, 254-258. [CrossRef]

29. Schulte, L.H.; Allers, A.; May, A. Hypothalamus as a mediator of chronic migraine Evidence from high-resolution fMRI. Neurology 2017, 88, 2011-2016. [CrossRef] [PubMed]

30. Cernuda-Morollón, E.; Larrosa, D.; Ramón, C.; Vega, J.; Martínez-Camblor, P.; Pascual, J. Interictal increase of CGRP levels in peripheral blood as a biomarker for chronic migraine. Neurology 2013, 81, 1191-1196. [CrossRef]

31. Cosentino, G.; Fierro, B.; Vigneri, S.; Talamanca, S.; Paladino, P.; Baschi, R.; Indovino, S.; Maccora, S.; Valentino, F.; Fileccia, E.; et al. Cyclical changes of cortical excitability and metaplasticity in migraine: Evidence from a repetitive transcranial magnetic stimulation study. Pain 2014, 155, 1070-1078. [CrossRef] [PubMed]

32. Bilgiç, B.; Kocaman, G.; Arslan, A.B.; Noyan, H.; Sherifov, R.; Alkan, A.; Asil, T.; Parman, Y.; Baykan, B. Volumetric differences suggest involvement of cerebellum and brainstem in chronic migraine. Cephalalgia 2016, 36, 301-308. [CrossRef] [PubMed]

33. de Tommaso, M.; Valeriani, M.; Guido, M.; Libro, G.; Specchio, L.M.; Tonali, P.; Puca, F. Abnormal brain processing of cutaneous pain in patients with chronic migraine. Pain 2003, 101, 25-32. [CrossRef]

34. Coppola, G.; Di Renzo, A.; Petolicchio, B.; Tinelli, E.; Di Lorenzo, C.; Parisi, V.; Serrao, M.; Calistri, V.; Tardioli, S.; Cartocci, G.; et al. Aberrant interactions of cortical networks in chronic migraine: A resting-state fMRI study. Neurology 2019, 92, E2550-E2558. [CrossRef] [PubMed]

35. Irimia, P.; Martínez-Valbuena, I.; Mínguez-Olaondo, A.; Domínguez-Vivero, C.; Sánchez-Arias, J.A.; Martínez-Vila, E.; Luquin, M.R.; Leira, R. Interictal amylin levels in chronic migraine patients: A case-control study. Cephalalgia 2021, 41, 604-612. [CrossRef]

36. Srikiatkhachorn, A.; Le Grand, S.M.; Supornsilpchai, W.; Storer, R.J. Pathophysiology of medication overuse headache-An update. Headache 2014, 54, 204-210. [CrossRef] [PubMed]

37. Coppola, G.; Currà, A.; Di Lorenzo, C.; Parisi, V.; Gorini, M.; Sava, S.L.; Schoenen, J.; Pierelli, F. Abnormal cortical responses to somatosensory stimulation in medication-overuse headache. BMC Neurol. 2010, 10, 126. [CrossRef]

38. Shibata, Y.; Ishiyama, S.; Matsushita, A. White matter diffusion abnormalities in migraine and medication overuse headache: A 1.5-T tract-based spatial statistics study. Clin. Neurol. Neurosurg. 2018, 174, 167-173. [CrossRef]

39. Ayzenberg, I.; Oberman, M.; Leineweber, K.; Franke, L.; Yoon, M.S.; Diener, H.C.; Katsarava, Z. Increased activity of serotonin uptake in platelets in medication overuse headache following regular intake of analgesics and triptans. J. Headache Pain 2008, 9, 109-112. [CrossRef]

40. Cortese, F.; Pierelli, F.; Pauri, F.; Di Lorenzo, C.; Lepre, C.; Malavolta, G.; Merluzzo, C.; Parisi, V.; Serrao, M.; Coppola, G. Short-term cortical synaptic depression/potentiation mechanisms in chronic migraine patients with or without medication overuse. Cephalalgia 2019, 39, 237-244. [CrossRef]

41. Rossi, C.; Pini, L.A.; Cupini, M.L.; Calabresi, P.; Sarchielli, P. Endocannabinoids in platelets of chronic migraine patients and medication-overuse headache patients: Relation with serotonin levels. Eur. J. Clin. Pharmacol. 2008, 64, 1-8. [CrossRef]

42. Perrotta, A.; Serrao, M.; Sandrini, G.; Burstein, R.; Sances, G.; Rossi, P.; Bartolo, M.; Pierelli, F.; Nappi, G. Sensitisation of spinal cord pain processing in medication overuse headache involves supraspinal pain control. Cephalalgia 2010, 30, 272-284. [CrossRef]

43. Lai, T.H.; Wang, S.J. Neuroimaging Findings in Patients with Medication Overuse Headache. Curr. Pain Headache Rep. 2018, $22,1$. [CrossRef] [PubMed]

44. Torta, D.M.; Costa, T.; Luda, E.; Barisone, M.G.; Palmisano, P.; Duca, S.; Geminiani, G.; Cauda, F. Nucleus accumbens functional connectivity discriminates medication-overuse headache. NeuroImage Clin. 2016, 11, 686-693. [CrossRef] 
45. Greco, R.; Demartini, C.; Zanaboni, A.M.; Tumelero, E.; De Icco, R.; Sances, G.; Allena, M.; Tassorelli, C. Peripheral changes of endocannabinoid system components in episodic and chronic migraine patients: A pilot study. Cephalalgia 2021, 41, 185-196. [CrossRef]

46. Andersen, H.H.; Duroux, M.; Gazerani, P. Serum MicroRNA Signatures in Migraineurs During Attacks and in Pain-Free Periods. Mol. Neurobiol. 2016, 53, 1494-1500. [CrossRef] [PubMed]

47. Yamanaka, G.; Suzuki, S.; Morishita, N.; Takeshita, M.; Kanou, K.; Takamatsu, T.; Suzuki, S.; Morichi, S.; Watanabe, Y.; Ishida, Y.; et al. Role of neuroinflammation and blood-brain barrier permutability on migraine. Int. J. Mol. Sci. 2021, 22, 8929. [CrossRef]

48. Welch, K.M.A.; Chabi, E.V.A.; Bartosh, K.; Achar, V.S.; Meyer, J.S. Cerebrospinal Fluid Y Aminobutyric Acid Levels in Migraine. BMJ 1975, 516-517. [CrossRef] [PubMed]

49. Marukawa, H.; Shimomura, T.; Takahashi, K. Salivary substance P, 5-hydroxytryptamine, and $\gamma$-aminobutyric acid levels in migraine and tension-type headache. Headache 1996, 36, 100-104. [CrossRef]

50. Gallelli, L.; Cione, E.; Peltrone, F.; Siviglia, S.; Verano, A.; Chirchiglia, D.; Zampogna, S.; Guidetti, V.; Sammartino, L.; Montana, A.; et al. Hsa-miR-34a-5p and hsa-miR-375 as Biomarkers for Monitoring the Effects of Drug Treatment for Migraine Pain in Children and Adolescents: A Pilot Study. J. Clin. Med. 2019, 8, 928. [CrossRef]

51. Greco, R.; De Icco, R.; Demartini, C.; Zanaboni, A.M.; Tumelero, E.; Sances, G.; Allena, M.; Tassorelli, C. Plasma levels of CGRP and expression of specific microRNAs in blood cells of episodic and chronic migraine subjects: Towards the identification of a panel of peripheral biomarkers of migraine? J. Headache Pain 2020, 21, 122. [CrossRef]

52. De Icco, R.; Fiamingo, G.; Greco, R.; Bottiroli, S.; Demartini, C.; Zanaboni, A.M.; Allena, M.; Guaschino, E.; Martinelli, D.; Putortì, A.; et al. Neurophysiological and biomolecular effects of erenumab in chronic migraine: An open label study. Cephalalgia 2020, 40, 1336-1345. [CrossRef]

53. Abouheif, M.M.; Nakasa, T.; Shibuya, H.; Niimoto, T.; Kongcharoensombat, W.; Ochi, M. Silencing microRNA-34a inhibits chondrocyte apoptosis in a rat osteoarthritis model in vitro. Rheumatology 2010, 49, 2054-2060. [CrossRef]

54. Endisha, H.; Datta, P.; Sharma, A.; Nakamura, S.; Rossomacha, E.; Younan, C.; Ali, S.A.; Tavallaee, G.; Lively, S.; Potla, P.; et al. MicroRNA-34a-5p Promotes Joint Destruction During Osteoarthritis. Arthritis Rheumatol. 2021, 73, 426-439. [CrossRef] [PubMed]

55. Cosín-Tomás, M.; Antonell, A.; Lladó, A.; Alcolea, D.; Fortea, J.; Ezquerra, M.; Lleó, A.; Martí, M.J.; Pallàs, M.; Sanchez-Valle, R.; et al. Plasma miR-34a-5p and miR-545-3p as Early Biomarkers of Alzheimer's Disease: Potential and Limitations. Mol. Neurobiol. 2017, 54, 5550-5562. [CrossRef] [PubMed]

56. Tazawa, H.; Tsuchiya, N.; Izumiya, M.; Nakagama, H. Tumor-suppressive miR-34a induces senescence-like growth arrest through modulation of the E2F pathway in human colon cancer cells. Proc. Natl. Acad. Sci. USA 2007, 104, 15472-15477. [CrossRef]

57. Zarone, M.R.; Misso, G.; Grimaldi, A.; Zappavigna, S.; Russo, M.; Amler, E.; Di Martino, M.T.; Amodio, N.; Tagliaferri, P.; Tassone, P.; et al. Evidence of novel miR-34a-based therapeutic approaches for multiple myeloma treatment. Sci. Rep. 2017, 7, 17949. [CrossRef]

58. Zanette, D.L.; Rivadavia, F.; Molfetta, G.A.; Barbuzano, F.G.; Proto-Siqueira, R.; Falcão, R.P.; Zago, M.A.; Silva, W.A. miRNA expression profiles in chronic lymphocytic and acute lymphocytic leukemia. Braz. J. Med. Biol. Res. 2007, 40, 1435-1440. [CrossRef]

59. Raver-Shapira, N.; Marciano, E.; Meiri, E.; Spector, Y.; Rosenfeld, N.; Moskovits, N.; Bentwich, Z.; Oren, M. Transcriptional Activation of miR-34a Contributes to p53-Mediated Apoptosis. Mol. Cell 2007, 26, 731-743. [CrossRef] [PubMed]

60. Chang, T.C.; Wentzel, E.A.; Kent, O.A.; Ramachandran, K.; Mullendore, M.; Lee, K.H.; Feldmann, G.; Yamakuchi, M.; Ferlito, M.; Lowenstein, C.J.; et al. Transactivation of miR-34a by p53 Broadly Influences Gene Expression and Promotes Apoptosis. Mol. Cell 2007, 26, 745-752. [CrossRef] [PubMed]

61. Jiang, P.; Liu, R.; Zheng, Y.; Liu, X.; Chang, L.; Xiong, S.; Chu, Y. MiR-34a inhibits lipopolysaccharide-induced inflammatory response through targeting Notch1 in murine macrophages. Exp. Cell Res. 2012, 318, 1175-1184. [CrossRef]

62. Mathé, E.; Nguyen, G.H.; Funamizu, N.; He, P.; Moake, M.; Croce, C.M.; Hussain, S.P. Inflammation regulates microRNA expression in cooperation with $\mathrm{p} 53$ and nitric oxide. Int. J. Cancer 2012, 131, 760-765. [CrossRef] [PubMed]

63. Tian, F.; Wang, J.; Zhang, Z.; Yang, J. LncRNA SNHG7/miR-34a-5p/SYVN1 axis plays a vital role in proliferation, apoptosis and autophagy in osteoarthritis. Biol. Res. 2020, 53, 9. [CrossRef]

64. Yan, S.; Wang, M.; Zhao, J.; Zhang, H.; Zhou, C.; Jin, L.; Zhang, Y.; Qiu, X.; Ma, B.; Fan, Q. MicroRNA-34a affects chondrocyte apoptosis and proliferation by targeting the SIRT1/p53 signaling pathway during the pathogenesis of osteoarthritis. Int. J. Mol. Med. 2016, 38, 201-209. [CrossRef] [PubMed]

65. Brinjikji, W.; Diehn, F.E.; Jarvik, J.G.; Carr, C.M.; Kallmes, D.F.; Murad, M.H.; Luetmer, P.H. MRI findings of disc degeneration are more prevalent in adults with low back pain than in asymptomatic controls: A systematic review and meta-analysis. Am. J. Neuroradiol. 2015, 36, 2394-2399. [CrossRef] [PubMed]

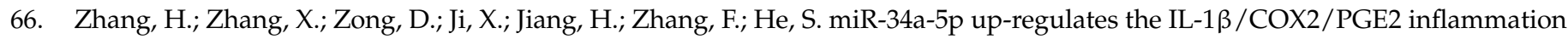
pathway and induces the release of CGRP via inhibition of SIRT1 in rat trigeminal ganglion neurons. FEBS Open Bio 2021, 11, 300-311. [CrossRef] [PubMed]

67. Zhang, H.; He, S.D.; Zong, D.D.; Zhang, X.M.; Luo, J.; Zheng, J.K. Effects of electroacupuncture on miR-34a-5p/SIRT1 signaling in the trigeminal ganglion of rats with migraine. Zhen Ci Yan Jiu 2020, 45, 868-874. [CrossRef]

68. Chen, S.; Gu, Y.; Dai, Q.; He, Y.; Wang, J. Spinal miR-34a regulates inflammatory pain by targeting SIRT1 in complete Freund's adjuvant mice. Biochem. Biophys. Res. Commun. 2019, 516, 1196-1203. [CrossRef] 
69. Yang, H.; Zhang, W.; Pan, H.; Feldser, H.G.; Lainez, E.; Miller, C.; Leung, S.; Zhong, Z.; Zhao, H.; Sweitzer, S.; et al. SIRT1 Activators Suppress Inflammatory Responses through Promotion of p65 Deacetylation and Inhibition of NF- $\mathrm{kB}$ Activity. PLoS ONE 2012, 7, e46364. [CrossRef]

70. Brandenburger, T.; Johannsen, L.; Prassek, V.; Kuebart, A.; Raile, J.; Wohlfromm, S.; Köhrer, K.; Huhn, R.; Hollmann, M.W.; Hermanns, H. MiR-34a is differentially expressed in dorsal root ganglia in a rat model of chronic neuropathic pain. Neurosci. Lett. 2019, 708, 134365. [CrossRef]

71. Madrigal, M.P.; Portalés, A.; SanJuan, M.P.; Jurado, S. Postsynaptic SNARE Proteins: Role in Synaptic Transmission and Plasticity. Neuroscience 2019, 420, 12-21. [CrossRef] [PubMed]

72. Quintas, M.; Neto, J.L.; Sequeiros, J.; Sousa, A.; Pereira-Monteiro, J.; Lemos, C.; Alonso, I. Going Deep into Synaptic Vesicle Machinery Genes and Migraine Susceptibility-A Case-Control Association Study. Headache 2020, 60, 2152-2165. [CrossRef] [PubMed]

73. Hung, K.L.; Wang, S.J.; Wang, Y.C.; Chiang, T.R.; Wang, C.C. Upregulation of presynaptic proteins and protein kinases associated with enhanced glutamate release from axonal terminals (synaptosomes) of the medial prefrontal cortex in rats with neuropathic pain. Pain 2014, 155, 377-387. [CrossRef]

74. Ishizaki, K.; Takeshima, T.; Fukuhara, Y.; Araki, H.; Nakaso, K.; Kusumi, M.; Nakashima, K. Increased plasma transforming growth factor- $\beta 1$ in migraine. Headache 2005, 45, 1224-1228. [CrossRef]

75. Вø, S.H.; Davidsen, E.M.; Gulbrandsen, P.; Dietrichs, E.; Bovim, G.; Stovner, L.J.; White, L.R. Cerebrospinal fluid cytokine levels in migraine, tension-type headache and cervicogenic headache. Cephalalgia 2009, 29, 365-372. [CrossRef] [PubMed]

76. Lin, C.A.; Duan, K.Y.; Wang, X.W.; Zhang, Z.S. Study on the role of Hsa-miR-382-5p in epidural fibrosis. Eur. Rev. Med. Pharmacol. Sci. 2018, 22, 3663-3668. [CrossRef]

77. Rossi, C.; Zini, R.; Rontauroli, S.; Ruberti, S.; Prudente, Z.; Barbieri, G.; Bianchi, E.; Salati, S.; Genovese, E.; Bartalucci, N.; et al. Role of TGF- $\beta 1 / \mathrm{miR}-382-5 \mathrm{p} / \mathrm{SOD} 2$ axis in the induction of oxidative stress in CD34+ cells from primary myelofibrosis. Mol. Oncol. 2018, 12, 2102-2123. [CrossRef]

78. Kriegel, A.J.; Fang, Y.; Liu, Y.; Tian, Z.; Mladinov, D.; Matus, I.R.; Ding, X.; Greene, A.S.; Liang, M. MicroRNA-target pairs in human renal epithelial cells treated with transforming growth factor $\beta 1$ : A novel role of miR-382. Nucleic Acids Res. 2010, 38, 8338-8347. [CrossRef]

79. Kato, M.; Zhang, J.; Wang, M.; Lanting, L.; Yuan, H.; Rossi, J.J.; Natarajan, R. MicroRNA-192 in diabetic kidney glomeruli and its function in TGF- $\beta$-induced collagen expression via inhibition of E-box repressors. Proc. Natl. Acad. Sci. USA 2007, 104, $3432-3437$. [CrossRef] [PubMed]

80. Yorns, W.R.; Hardison, H.H. Mitochondrial dysfunction in migraine. Semin. Pediatr. Neurol. 2013, 20, 188-193. [CrossRef]

81. Borkum, J.M. Migraine Triggers and Oxidative Stress: A Narrative Review and Synthesis. Headache 2016, 56, 12-35. [CrossRef]

82. Li, R.; Liu, Y.; Chen, N.; Zhang, Y.; Song, G.; Zhang, Z. Valproate attenuates nitroglycerin-induced trigeminovascular activation by preserving mitochondrial function in a Rat model of migraine. Med. Sci. Monit. 2016, 22, 3229-3237. [CrossRef] [PubMed]

83. Xiang, W.; Jiang, L.; Zhou, Y.; Li, Z.; Zhao, Q.; Wu, T.; Cao, Y.; Zhou, J. The lncRNA Ftx/miR-382-5p/Nrg1 axis improves the inflammation response of microglia and spinal cord injury repair. Neurochem. Int. 2021, 143, 104929. [CrossRef] [PubMed]

84. Wan, C.; Xu, Y.; Cen, B.; Xia, Y.; Yao, L.; Zheng, Y.; Zhao, J.; He, S.; Chen, Y. Neuregulin1-ErbB4 Signaling in Spinal Cord Participates in Electroacupuncture Analgesia in Inflammatory Pain. Front. Neurosci. 2021, 15, 636348. [CrossRef] [PubMed]

85. Kataria, H.; Alizadeh, A.; Karimi-Abdolrezaee, S. Neuregulin-1/ErbB network: An emerging modulator of nervous system injury and repair. Prog. Neurobiol. 2019, 180, 101643. [CrossRef]

86. Wang, G.; Dai, D.; Chen, X.; Yuan, L.; Zhang, A.; Lu, Y.; Zhang, P. Upregulation of neuregulin-1 reverses signs of neuropathic pain in rats. Int. J. Clin. Exp. Pathol. 2014, 7, 5916-5921.

87. Alizadeh, A.; Dyck, S.M.; Kataria, H.; Shahriary, G.M.; Nguyen, D.H.; Santhosh, K.T.; Karimi-Abdolrezaee, S. Neuregulin-1 positively modulates glial response and improves neurological recovery following traumatic spinal cord injury. Glia 2017, 65, 1152-1175. [CrossRef]

88. Reuter, U.; Chiarugi, A.; Bolay, H.; Moskowitz, M.A. Nuclear factor-кB as a molecular target for migraine therapy. Ann. Neurol. 2002, 51, 507-516. [CrossRef] [PubMed]

89. Greco, R.; Tassorelli, C.; Cappelletti, D.; Sandrini, G.; Nappi, G. Activation of the Transcription Factor NF-kB in the nucleus trigeminalis caudalis in an animal model of migraine. Neurotoxicology 2005, 26, 795-800. [CrossRef] [PubMed]

90. Sarchielli, P.; Floridi, A.; Mancini, M.L.; Rossi, C.; Coppola, F.; Baldi, A.; Pini, L.A.; Calabresi, P. NF-kB activity and iNOS expression in monocytes from internal jugular blood of migraine without aura patients during attacks. Cephalalgia 2006, 26, 1071-1079. [CrossRef]

91. Novák, J.; Olejníčková, V. microRNA: Basic Science; Springer International Publishing: Cham, Switzerland, 2015; Volume 887, pp. 79-100. [CrossRef]

92. Wang, X.; Xue, N.; Zhao, S.; Shi, Y.; Ding, X.; Fang, Y. Upregulation of miR-382 contributes to renal fibrosis secondary to aristolochic acid-induced kidney injury via PTEN signaling pathway. Cell Death Dis. 2020, 11, 620. [CrossRef]

93. Zhai, Y.; Zhu, Y.Y. MiR-30a relieves migraine by degrading CALCA. Eur. Rev. Med. Pharmacol. Sci. 2018, 22, 2022-2028. [CrossRef]

94. Tafuri, E.; Santovito, D.; De Nardis, V.; Marcantonio, P.; Paganelli, C.; Affaitati, G.; Bucci, M.; Mezzetti, A.; Giamberardino, M.A.; Cipollone, F. MicroRNA profiling in migraine without aura: Pilot study. Ann. Med. 2015, 47, 468-473. [CrossRef] 
95. Cheng, C.Y.; Chen, S.P.; Liao, Y.C.; Fuh, J.L.; Wang, Y.F.; Wang, S.J. Elevated circulating endothelial-specific microRNAs in migraine patients: A pilot study. Cephalalgia 2018, 38, 1585-1591. [CrossRef] [PubMed]

96. Cannataro, R.; Caroleo, M.C.; Siniscalchi, A.; Gallelli, L.; De Sarro, G.; Cione, E. Ketogenic Diet Modifies the Expression of MicroRNAs Linked to Migraine. Acta Sci. Nutr. Health 2020, 4, 34-41.

97. Zhu, Q.; Li, H.; Li, Y.; Jiang, L. MicroRNA-30a functions as tumor suppressor and inhibits the proliferation and invasion of prostate cancer cells by down-regulation of SIX1. Hum. Cell 2017, 30, 290-299. [CrossRef] [PubMed]

98. Shepard, A.; Hoxha, S.; Troutman, S.; Harbaugh, D.; Kareta, M.S.; Kissil, J.L. Transcriptional regulation of miR-30a by YAP impacts PTPN13 and KLF9 levels and Schwann cell proliferation. J. Biol. Chem. 2021, 297, 100962. [CrossRef]

99. Li, J.; Xie, Y.; Li, L.; Li, X.; Shen, L.; Gong, J.; Zhang, R. MicroRNA-30a Modulates Type I Interferon Responses to Facilitate Coxsackievirus B3 Replication Via Targeting Tripartite Motif Protein 25. Front. Immunol. 2021, 11, 603437. [CrossRef]

100. Li, Y.; Zhang, J.; Liu, Y.; Zhang, B.; Zhong, F.; Wang, S.; Fang, Z. MiR-30a-5p confers cisplatin resistance by regulating IGF1R expression in melanoma cells. BMC Cancer 2018, 18, 404. [CrossRef] [PubMed]

101. Shi, S.; Yu, L.; Zhang, T.; Qi, H.; Xavier, S.; Ju, W.; Bottinger, E. Smad2-Dependent Downregulation of miR-30 Is Required for TGF- $\beta$-Induced Apoptosis in Podocytes. PLoS ONE 2013, 8, e75572. [CrossRef]

102. Volkmann, I.; Kumarswamy, R.; Pfaff, N.; Fiedler, J.; Dangwal, S.; Holzmann, A.; Batkai, S.; Geffers, R.; Lother, A.; Hein, L.; et al. MicroRNA-mediated epigenetic silencing of sirtuin1 contributes to impaired angiogenic responses. Circ. Res. 2013, 113, 997-1003. [CrossRef] [PubMed]

103. Chen, H.; Wang, Y.; Xu, Y.; Wang, G.N. Overexpression of miR-30a attenuates neuropathic pain by targeting SOCS1 in rats with chronic constriction injury. Int. J. Clin. Exp. Pathol. 2016, 9, 1258-1266.

104. Tan, M.; Shen, L.; Hou, Y. Epigenetic modification of BDNF mediates neuropathic pain via miR-30a-3p/EP300 axis in CCI rats. Biosci. Rep. 2020, 40, BSR20194442. [CrossRef]

105. Zhong, M.; Bian, Z.; Wu, Z. MiR-30a suppresses cell migration and invasion through downregulation of PIK3CD in colorectal carcinoma. Cell. Physiol. Biochem. 2013, 31, 209-218. [CrossRef]

106. Zhang, L.; Cheng, R.; Huang, Y. MiR-30a inhibits BECN1-mediated autophagy in diabetic cataract. Oncotarget 2017, 8, 77360-77368. [CrossRef] [PubMed]

107. Chen, S.-P.; Zhou, Y.-Q.; Liu, D.-Q.; Zhang, W.; Manyande, A.; Guan, X.-H.; Tian, Y.; Ye, D.-W.; Omar, D.M. PI3K/Akt Pathway: A Potential Therapeutic Target for Chronic Pain. Curr. Pharm. Des. 2017, 23, 1860-1868. [CrossRef] [PubMed]

108. Liu, W.; Lv, Y.; Ren, F. PI3K/Akt Pathway is Required for Spinal Central Sensitization in Neuropathic Pain. Cell. Mol. Neurobiol. 2018, 38, 747-755. [CrossRef] [PubMed]

109. Guo, J.-R.; Wang, H.; Jin, X.-J.; Jia, D.-L.; Zhou, X.; Tao, Q. Effect and mechanism of inhibition of PI3K/Akt/mTOR signal pathway on chronic neuropathic pain and spinal microglia in a rat model of chronic constriction injury. Oncotarget 2017, 8, 52923-52934. [CrossRef] [PubMed]

110. Zhang, S.; Liu, H.; Liu, Y.; Zhang, J.; Li, H.; Liu, W.; Cao, G.; Xv, P.; Zhang, J.; Lv, C.; et al. miR-30a as potential therapeutics by targeting tet1 through regulation of Drp-1 promoter hydroxymethylation in idiopathic pulmonary fibrosis. Int. J. Mol. Sci. 2017, 18, 633. [CrossRef] [PubMed]

111. Hsieh, M.C.; Lai, C.Y.; Ho, Y.C.; Wang, H.H.; Cheng, J.K.; Chau, Y.P.; Peng, H.Y. Tet1-dependent epigenetic modification of BDNF expression in dorsal horn neurons mediates neuropathic pain in rats. Sci. Rep. 2016, 6, 37411. [CrossRef]

112. Pan, Z.; Xue, Z.Y.; Li, G.F.; Sun, M.L.; Zhang, M.; Hao, L.Y.; Tang, Q.Q.; Zhu, L.J.; Cao, J.L. DNA Hydroxymethylation by Ten-eleven Translocation Methylcytosine Dioxygenase 1 and 3 Regulates Nociceptive Sensitization in a Chronic Inflammatory Pain Model. Anesthesiology 2017, 127, 147-163. [CrossRef] [PubMed]

113. Migraine Research Foundation. Final Report: microRNA Expression Profile in Migraine: The microMIG Study. New York: Migraine Research Foundation. 2019. Available online: https://migraineresearchfoundation.org/researchers/patricia-pozorosich-md-phd/ (accessed on 9 October 2021).

114. Burstein, R.; Perry, C.; Blake, P.; Buettner, C.; Bhasin, M. EHMTI-0354. Abnormal expression of gene transcripts linked to inflammatory response in the periosteum of chronic migraine patients: Implications to extracranial origin of headache. J. Headache Pain 2014, 15, K2. [CrossRef]

115. Chen, Y.-H.; Wang, H. The Association between Migraine and Depression based on miRNA Biomarkers and Cohort Studies. Curr. Med. Chem. 2021, 28, 5648-5656. [CrossRef] [PubMed]

116. Qureshi, R.A.; Tian, Y.; McDonald, M.K.; Capasso, K.E.; Douglas, S.R.; Gao, R.; Orlova, I.A.; Barrett, J.E.; Ajit, S.K.; Sacan, A. Circulating microRNA Signatures in Rodent Models of Pain. Mol. Neurobiol. 2016, 53, 3416-3427. [CrossRef] [PubMed]

117. Chen, X.; Li, B.; Luo, R.; Cai, S.; Zhang, C.; Cao, X. Analysis of the function of microRNA-375 in humans using bioinformatics. Biomed. Rep. 2017, 6, 561-566. [CrossRef]

118. Cannataro, R.; Caroleo, M.C.; Fazio, A.; La Torre, C.; Plastina, P.; Gallelli, L.; Lauria, G.; Cione, E. Ketogenic diet and microRNAs linked to antioxidant biochemical homeostasis. Antioxidants 2019, 8, 269. [CrossRef] [PubMed]

119. Di Lorenzo, C.; Coppola, G.; Bracaglia, M.; Di Lenola, D.; Sirianni, G.; Rossi, P.; Di Lorenzo, G.; Parisi, V.; Serrao, M.; Cervenka, M.C.; et al. A ketogenic diet normalizes interictal cortical but not subcortical responsivity in migraineurs. BMC Neurol. 2019, 19, 136. [CrossRef] [PubMed]

120. Vila-Pueyo, M.; Fernández-Morales, J.; Torres-Ferrus, M.; Álvarez-Sabin, J.; Pozo-Rosich, P. EHMTI-0361. Lack of differences in microrna expression profiles of blood cells in migraine. J. Headache Pain 2014, 15, H3. [CrossRef] 
121. Andersen, H.H.; Duroux, M.; Gazerani, P. MicroRNAs as modulators and biomarkers of inflammatory and neuropathic pain conditions. Neurobiol. Dis. 2014, 71, 159-168. [CrossRef]

122. López-González, M.J.; Landry, M.; Favereaux, A. MicroRNA and chronic pain: From mechanisms to therapeutic potential. Pharmacol. Ther. 2017, 180, 1-15. [CrossRef]

123. Bai, G.; Ambalavanar, R.; Wei, D.; Dessem, D. Downregulation of selective microRNAs in trigeminal ganglion neurons following inflammatory muscle pain. Mol. Pain 2007, 3, 13-16. [CrossRef] [PubMed]

124. Wilkerson, J.L.; Jiang, J.; Felix, J.S.; Bray, J.K.; da Silva, L.; Gharaibeh, R.Z.; McMahon, L.R.; Schmittgen, T.D. Alterations in mouse spinal cord and sciatic nerve microRNAs after the chronic constriction injury (CCI) model of neuropathic pain. Neurosci. Lett. 2020, 731, 135029. [CrossRef]

125. Kusuda, R.; Cadetti, F.; Ravanelli, M.I.; Sousa, T.A.; Zanon, S.; De Lucca, F.L.; Lucas, G. Differential expression of microRNAs in mouse pain models. Mol. Pain 2011, 7, 17. [CrossRef]

126. Li, H.; Shen, L.; Ma, C.; Huang, Y. Differential expression of miRNAs in the nervous system of a rat model of bilateral sciatic nerve chronic constriction injury. Int. J. Mol. Med. 2013, 32, 219-226. [CrossRef]

127. Sakai, A.; Suzuki, H. Nerve injury-induced upregulation of miR-21 in the primary sensory neurons contributes to neuropathic pain in rats. Biochem. Biophys. Res. Commun. 2013, 435, 176-181. [CrossRef] [PubMed]

128. Karl, F.; Grießhammer, A.; Üçeyler, N.; Sommer, C. Differential impact of miR-21 on pain and associated affective and cognitive behavior after spared nerve injury in B7-H1 ko mouse. Front. Mol. Neurosci. 2017, 10, 219. [CrossRef]

129. Davis, K.D.; Aghaeepour, N.; Ahn, A.H.; Angst, M.S.; Borsook, D.; Brenton, A.; Burczynski, M.E.; Crean, C.; Edwards, R.; Gaudilliere, B.; et al. Discovery and validation of biomarkers to aid the development of safe and effective pain therapeutics: Challenges and opportunities. Nat. Rev. Neurol. 2020, 16, 381-400. [CrossRef] [PubMed]

130. Zhang, Z.J.; Guo, J.S.; Li, S.S.; Wu, X.B.; Cao, D.L.; Jiang, B.C.; Jing, P.B.; Bai, X.Q.; Li, C.H.; Wu, Z.H.; et al. TLR8 and its endogenous ligand miR-21 contribute to neuropathic pain in murine DRG. J. Exp. Med. 2018, 215, 3019-3037. [CrossRef]

131. Polli, A.; Godderis, L.; Ghosh, M.; Ickmans, K.; Nijs, J. Epigenetic and miRNA Expression Changes in People with Pain: A Systematic Review. J. Pain 2020, 21, 763-780. [CrossRef] [PubMed]

132. Masotti, A.; Baldassarre, A.; Guzzo, M.P.; Iannuccelli, C.; Barbato, C.; Di Franco, M. Circulating microRNA Profiles as Liquid Biopsies for the Characterization and Diagnosis of Fibromyalgia Syndrome. Mol. Neurobiol. 2017, 54, 7129-7136. [CrossRef]

133. Bjersing, J.L.; Bokarewa, M.I.; Mannerkorpi, K. Profile of circulating microRNAs in fibromyalgia and their relation to symptom severity: An exploratory study. Rheumatol. Int. 2015, 35, 635-642. [CrossRef]

134. Linnstaedt, S.D.; Riker, K.D.; Walker, M.G.; Nyland, J.E.; Zimny, E.; Lewandowski, C.; Hendry, P.L.; Damiron, K.; Pearson, C.; Velilla, M.A.; et al. MicroRNA 320a predicts chronic axial and widespread pain development following motor vehicle collision in a stress-dependent manner. J. Orthop. Sports Phys. Ther. 2016, 46, 911-919. [CrossRef]

135. Giannitti, C.; De Palma, A.; Pascarelli, N.A.; Cheleschi, S.; Giordano, N.; Galeazzi, M.; Fioravanti, A. Can balneotherapy modify microRNA expression levels in osteoarthritis? A comparative study in patients with knee osteoarthritis. Int. J. Biometeorol. 2017, 61, 2153-2158. [CrossRef] [PubMed]

136. Dayer, C.F.; Luthi, F.; Le Carré, J.; Vuistiner, P.; Terrier, P.; Benaim, C.; Giacobino, J.P.; Léger, B. Differences in the miRNA signatures of chronic musculoskeletal pain patients from neuropathic or nociceptive origins. PLoS ONE 2019, 14, e0219311. [CrossRef] [PubMed]

137. Kynast, K.L.; Russe, O.Q.; Geisslinger, G.; Niederberger, E. Novel findings in pain processing pathways: Implications for miRNAs as future therapeutic targets. Expert Rev. Neurother. 2013, 13, 515-525. [CrossRef] [PubMed]

138. Dai, Z.; Chu, H.; Ma, J.; Yan, Y.; Zhang, X.; Liang, Y. The regulatory mechanisms and therapeutic potential of microRNAs: From chronic pain to morphine tolerance. Front. Mol. Neurosci. 2018, 11, 80. [CrossRef] [PubMed]

139. Baumann, V.; Winkler, J. MiRNA-based therapies: Strategies and delivery platforms for oligonucleotide and non-oligonucleotide agents. Future Med. Chem. 2014, 6, 1967-1984. [CrossRef]

140. Christopher, A.; Kaur, R.; Kaur, G.; Kaur, A.; Gupta, V.; Bansal, P. MicroRNA therapeutics: Discovering novel targets and developing specific therapy. Perspect. Clin. Res. 2016, 7, 68. [CrossRef]

141. Christensen, C.E.; Younis, S.; Deen, M.; Khan, S.; Ghanizada, H.; Ashina, M. Migraine induction with calcitonin gene-related peptide in patients from erenumab trials. J. Headache Pain 2018, 19, 105. [CrossRef]

142. Kadir, R.R.A.; Alwjwaj, M.; Bayraktutan, U. MicroRNA: An Emerging Predictive, Diagnostic, Prognostic and Therapeutic Strategy in Ischaemic Stroke. Cell. Mol. Neurobiol. 2020. [CrossRef]

143. Hong, D.S.; Kang, Y.K.; Borad, M.; Sachdev, J.; Ejadi, S.; Lim, H.Y.; Brenner, A.J.; Park, K.; Lee, J.L.; Kim, T.Y.; et al. Phase 1 study of MRX34, a liposomal miR-34a mimic, in patients with advanced solid tumours. Br. J. Cancer 2020, 122, 1630-1637. [CrossRef] [PubMed] 